\title{
PENINGKATAN KUALITAS KESEHATAN LINGKUNGAN PRODUKSI PENGRAJIN TOPENG MALANGAN DAN SOUVENIR DI DESA JABUNG KABUPATEN MALANG
}

\author{
Wahyu Hidayat Riyanto ${ }^{1}$; Yunan Syaifullah²; Risky Angga Pramuja ${ }^{3}$ \\ Universitas Muhammadiyah Malang ${ }^{123}$
}

\begin{abstract}
The difficulty in the village of Jabung is the lack of greening of access to the place of the mask craftsmen so that the masked village looks barren. Then there is still low knowledge of waste / waste management and management of production environments that seem messy and how to dispose of the rest of the paint or ink paints and the low awareness of hygiene and health craftsmen that causes craftsmen not to use masks and gloves when making masks and other souvenirs. The solution to the problems that occur with mask craftsmen is by giving information on environmental hygiene so that the craftsmen's awareness will emerge on the importance of environmental hygiene. Besides that, it helps craftsmen in managing and managing the production environment of mask artisans. The result of this service is an increase in the quality of the cleanliness of the production environment. The cleanliness of the production environment has an impact on the comfort of the mask craftsmen in producing works so that the craftsmen are more active in creating and adding economic value.
\end{abstract}

Key words: Mask Village; Jabung Village; green village; Production management

\begin{abstract}
Abstrak
Kesuliatan yang dihadapi di desa jabung adalah kurangnya penghijauan akses menuju tempat pengrajin topeng sehingga kampung topeng terlihat gersang. Kemudian masih rendahnya pengetahuan pengelolaan sampah/limbah dan manajemen lingkungan produksi yang terkesan berantakan serta bagaimana membuang sisa cat atau tinta lukis topeng dan masih rendahnya kesadaran pengrajin kebersihan dan kesehatan yang menyebabkan para pengrajin tidak menggunakan masker dan sarung tangan ketika membuat topeng dan souvenir lainnya. Penyelesaian masalah yang terjadi pada pengrajin topeng yaitu dengan cara memberi penyuluhan kebersihan lingkungan agar muncul kesadaran para pengrajin akan pentingnya kebersihan lingkungan. Selain itu membantu pengrajin dalam hal mengatur serta menata lingkungan produksi pengrajin topeng. Hasil dari pengabdian ini yaitu adanya peningkatan kualitas kebersihan lingkungan produksi. Kebersihan lingkungan produksi berdampak pada kenyamanan pengrajin topeng dalam menghasilkan karya sehingga para pengrajin lebih giat dalam berkarya dan memberi nilai tambah ekonomi.
\end{abstract}

Kata kunci: Kampung Topeng; Desa Jabung; penghijauan; manajemen produksi

\section{PENDAHULUAN}

Kabupaten Malang memiliki 33 kecamatan. kecamatan Jabung adalah salah satu wilayah yang berada di kabupaten malang. Desa Jabung terletak di kecamatan jabung, memiliki penduduk 9.224 jiwa dan luas wilayah 705,78 ha. Jumlah Kepala keluarga atau KK sebanyak 2564 dengan rata-rata anggota keluarga 4 orang per keluarga. Indeks desa membangun desa jabung 0,656 yang termasuk klasifikasi berkembang. Hal ini berarti desa jabung adalah desa yang memiliki potensi-potensi desa yang perlu dikembangkan dan perlu sentuhan dan kontribusi nyata (Kementerian Desa, 2015). Dalam konsep pentahalix yaitu pemerintah, masyarakat, business, media dan akademisi. Konsep tersebut bekerja secara bersama-sama menuju pencapaian desa yang mandiri. Dalam meningkat daya saing desa dalam hal pembangunan maka sebuah desa harus memiliki ciri khas yang harus dijual kepada publik melalui potensi-potensi yang dimiliki desa. Potensi yang ada didesa dikembangkan berbasis kearifan lokal melalui peningkatan

\footnotetext{
${ }^{1}$ Email: wahyu24365@gmail.com
} 
produk-produk didesa yang memiliki daya saing dan daya tarik. Terkadang pemerintah desa atau perangkat desa kesulitan untuk mendorong potensi yang ada.

Pariwisata adalah salah satu industri yang sangat strategis dan dapat dikembangkan di desa jabung. Industri pariwisata memiliki sub sektor yang beragam. Artinya industri ini adalah industri yang sempurna karena memberikan effect multiplier pada wilayah sekitarnya. Salah satu industri tersebut adalah obyek wisata, kesenian, seni/budaya, dan sarana lainnya. Jabung memilkik 2 group seni musik, 1 group tari, dan 2 seni rupa. Desa jabung adalah desa yang memiliki group seni tari di kecamatan jabung dan group seni rupa di kecamatan jabung hanya dimiliki oleh desa jabung dan desa sukopuro.

"Kampung topeng" adalah sebuah nama kampung yang berada di desa jabung. Kampung ini mengapa disebut kampung topeng dikarenakan banyak penggiat-penggiat seni rupa topeng malangan. Penggiat topeng malangan dijabung selain memproduksi topeng juga memproduksi cindramata atau oleh khas desa jabung seperti vandel, gantungan kunci, sampai coklat manis berbentuk topeng. Selain itu desa jabung juga memiliki group tari malangan tentunya Penggiat topeng di desa jabung keberadaannya kurang terxpose ke publik.

Pernyataan pihak mitra melalui wawancara dan observasi diketahui beberapa permasalahan dan kendalanya adalah sebagai berikut (1) Kurang penghijauan akses menuju tempat pengrajin topeng sehingga kampung topeng terlihat gersang (2) Masih rendahnya pengetahuan pengelolaan sampah/limbah bagaiamana membuang sisa cat atau tinta lukis topeng (3) Masih rendahnya kesadaran pengrajin kebersihan dan kesehatan lokasi produksi yang terkesan berantakan menyebabkan para pengrajin tidak nyaman serta penggunaan masker ketika membuat topeng dan souvenir lainnya.

Tujuan dari kegiatan pengabdian ini adalah (1) adanya penghijauan limgkungan (2) memberi wawasan Pengrajin topeng malangan di desa jabung tentang pentingnya pengelolaan sampah/limbah serta kesehatan lingkungan. (3) adanya kerapihan tempat lingkungan produksi. Manfaat kegiatan pengabdian ini adalah adanya peningkatan kesehatan dan kebersihan lingkungan para penggiat topeng malangan dan souvenir. Kemudian adanya peningkatan produktifitas para pengrajin karena faktor lingkungan tempat produksi yang bertambah baik. Dengan adanya produktifitas yang baik maka akan berimplikasi pada pendampatan para pengrajin topeng malangan dan soubenir di desa jabung.

\section{MATERI DAN METODE PELAKSANAAN}

Materi dalam pelaksanaan program pengabdian ini adalah konsep nilai ekonomi menurut Fauzi (Fauzi, 2010) nilai ekonomi tidak hanya berkaitan dengan nilai langsung dan tidak langsung. Nilai atau Value dapat diterjemahkan sebagai importance atau desirability. Penilaian dalam kerangka ekonomi dapat di jelaskan sebagai suati aktifitas penilaian yang berkaitan dengan perubahaan kesejahteraan ekonomi di masyarakat. Nilai ekonomi dari sumber daya alam dan lingkungan (economic value of ecosystem services) adalah penilaian pada konstribusi sumber daya alam dan lingkungan terhadap kesejahteraan.

Nilai sumber daya alam dan lingkungan Menurut Suparmoko dalam (Widyawati, 2014) dibedakan menjadi 2 yaitu nilai yang terkandung di dalamnya (intrinstic value atau non use value) dan nilai atas penggunaan (instrumental value atau use value). Nilai yang dimaksud yaitu kemampuan lingkungan jika digugakan atau dimanfaatkan. Menurut (Simungan, 2005), produktifitas tenaga kerja dipengaruhi salah satunya yaitu lingkungan kerja yang mendukung. Menurut Suardi 2007 dalam (Oktafiani, 2016) untuk mendapat 
nilai produktifitas tenaga kerja yang tinggi maka perusahaan harus memelihara kualitas dan kuantitas dari tenaga kerja dilingkungan kerja. Tenaga kerja yang dijamin kesehatan dan keselamatan kerja maka pekerja tersebut lebih produktif dibandingkan dengan yang tidak terjamin keselatan serta kesehatannya.

Adapun kegiatan pengabdian di desa jabung kabupaten Malang dilakukan dengan berbasis permasalahan di lapangan yang dikhususkan pada tema kesehatan lingkungan. Adapun alur kegiatan pengabdian yang dimulai dari tahap survey lokasi hingga evaluasi kebermanfaatan program (outcome) dapat terlihat pada gambar 1.

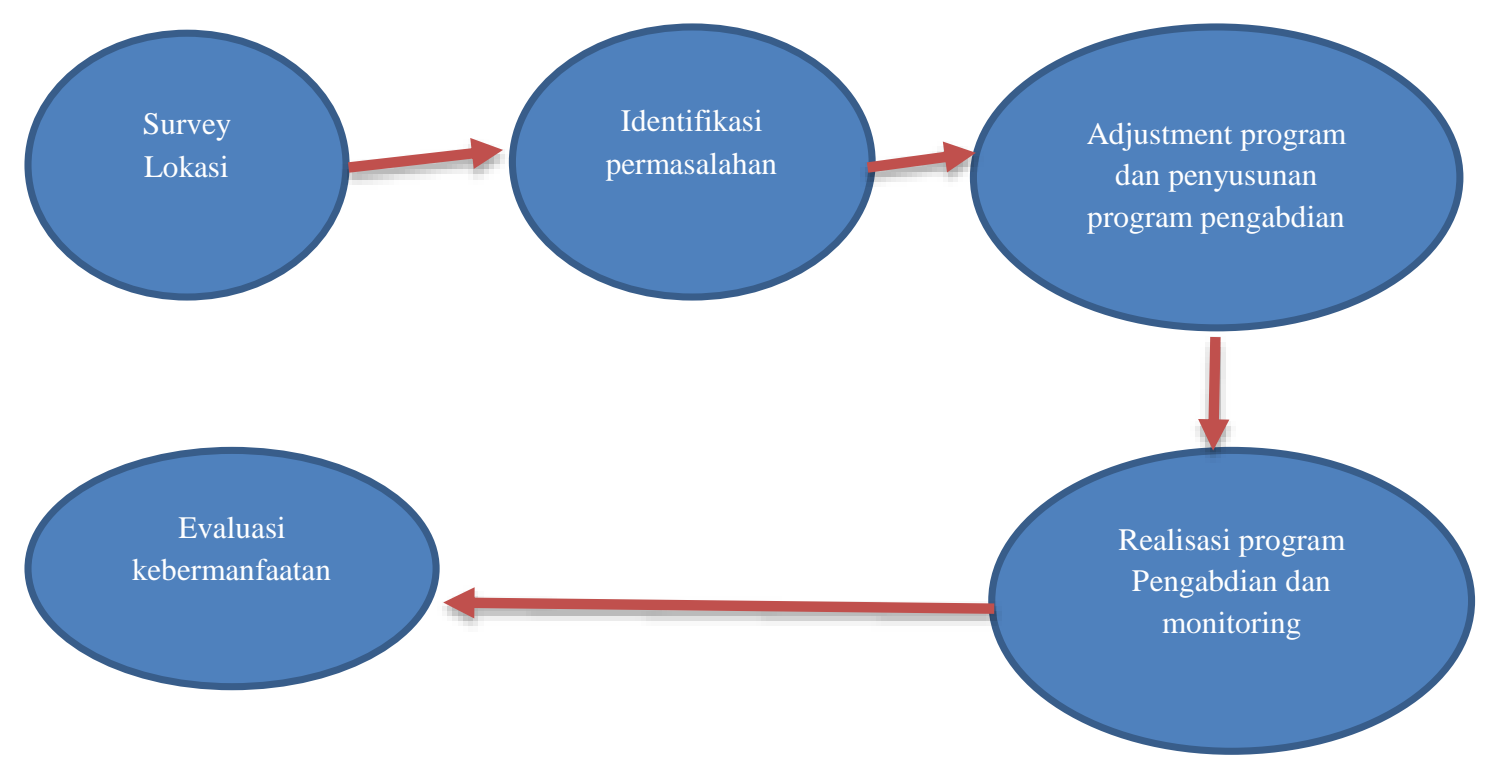

Gambar 1 Alur Kegiatan Program Pengabdian Desa Jabung

Teknik pelaksanaan dalam kegiatan dilakukan dengan beberapa aktifitas. Aktifitas kegiatan pengabdian di desa jabung ini dijelaskan dalam bentuk Tabel 1 dimana berisi teknis kegiatan, indikator capaian serta paramaternya.

Table 1. Aktifitas dan Indikator Capaian

\begin{tabular}{|c|c|c|c|}
\hline Aktifitas & $\begin{array}{l}\text { Teknis } \\
\text { Kegiatan }\end{array}$ & Indikator capaian & Parameternya \\
\hline $\begin{array}{l}\text { Persiapan dan Survey, } \\
\text { yaitu melakukan } \\
\text { koordinasi dengan tim } \\
\text { pengabdian dan mitra } \\
\text { serta perangkat desa } \\
\text { untuk menentukan waktu } \\
\text { dan tempat pelaksanaan } \\
\text { kegiatan serta } \\
\text { kesepakantan lainnya } \\
\text { mengenai prosedur serta } \\
\text { tahapan kegiatan. }\end{array}$ & $\begin{array}{c}\text { Diskusi dan } \\
\text { survey }\end{array}$ & $\begin{array}{l}\text { Masalah yang } \\
\text { berhasil } \\
\text { teridentifikasi yang } \\
\text { ada di desa jabung }\end{array}$ & $\begin{array}{l}\text { Jumlah program } \\
\text { yang bisa } \\
\text { terealisasi } \\
\text { menjawab } \\
\text { permasalahan yang } \\
\text { ada }\end{array}$ \\
\hline Pelaksanaan sosialisasi & Penyuluhan & Adanya kesadaran & Jumlah \\
\hline
\end{tabular}




\begin{tabular}{|c|c|c|c|}
\hline $\begin{array}{lr}\text { program } & \text { manajemen } \\
\text { lingkungan produksi dan } \\
\text { kesadaran } \\
\text { pengelolaan } \\
\text { kebersihan limbah dan } \\
\text { produksi }\end{array}$ & & $\begin{array}{l}\text { pengrajin topeng } \\
\text { dalam pengelolaan } \\
\text { limbah dan } \\
\text { kebersihan } \\
\text { lingkungan }\end{array}$ & $\begin{array}{l}\text { pengrajin yang ikut } \\
\text { penyuluhan. }\end{array}$ \\
\hline $\begin{array}{l}\text { Pendampingan penataan } \\
\text { tempat produksi } \\
\text { pengrajin topeng dan } \\
\text { penghijauan. } \\
\text { Evaluasi Kegiatan denga } \\
\text { cara berdiskusi tentang } \\
\text { hal-hal yang sudah } \\
\text { terlaksana bagaimana } \\
\text { hasil capaiannya serta } \\
\text { kebermanfaatan } \\
\text { program. }\end{array}$ & $\begin{array}{c}\text { Turun Lapang } \\
\text { dan } \\
\text { pendampingan }\end{array}$ & $\begin{array}{l}\text { Adanya penataan } \\
\text { tempat produksi } \\
\text { yang lebih bersih } \\
\text { dan sehat } \\
\text { Masalah yang } \\
\text { berhasil } \\
\text { teridentifikasi yang } \\
\text { ada di desa jabung } \\
\text { dan } \\
\text { kebermanfaatan } \\
\text { program. }\end{array}$ & $\begin{array}{l}\text { Perbedaan sebelum } \\
\text { dan sesudah } \\
\text { penataan tampat } \\
\text { produksi. } \\
\text { Permasalahan yang } \\
\text { terjawab dari } \\
\text { adanya program } \\
\text { pengabdian }\end{array}$ \\
\hline
\end{tabular}

Khalayak Sasaran utama dari program pengabdian kesehatan lingkungan berbasis masalah dilapangan adalah penggiat topeng malangan dan souvenir di desa jabung kabupaten malang.

Tabel 2 Khalayak Sasaran

\begin{tabular}{llllrl}
\hline Tema & Indikator & \multicolumn{2}{l}{ Khalayak Sasaran } & Waktu \\
Pelaksanaan
\end{tabular}




jabung dan Malang
kebermanfaatan
program.

Selain itu berdasarkan permasalah yang ada di desa jabung kabupaten Malang berdasarkan hasil evaluasi dan kegiatan monitoring terdapat 2 permasalahan yang akan terjawab dari program pengabdian ini yaitu penyuluhan program kesdaran kebersihan lingkungan dan kesehatan serta program penataan lokasi produksi topeng malangan. Metode yang digunakan dalam penyelesaian masalah dilakukan dengan cara partisipatif, penyuluhan dan pendampingan. Materi dan solusi yang ditawarkan dalam penyelesaian masalah adalah sebagai berikut:

1. Penyuluhan pada pengrajin topeng malangan di desa jabung dengan tema kebersihan lingkungan dan kesehatan

2. Pendampingan penataan tempat produksi topeng malangandi desa jabung

3. Melakukan monitoring dan evaluasi untuk keberhasilan serta keberlanjutan program.

Tebel 3 Evaluasi dan Monitoring Kegiatan Pengabdian

\begin{tabular}{|c|c|c|c|}
\hline $\mathrm{NO}$ & Kreteria & Indikator & $\begin{array}{l}\text { Paramater } \\
\text { keberhasilan }\end{array}$ \\
\hline 1 & $\begin{array}{l}\text { Survey Lokasi dan } \\
\text { dengan mitra }\end{array}$ & $\begin{array}{l}\text { Masalah yang } \\
\text { berhasil } \\
\text { teridentifikasi yang } \\
\text { ada di desa jabung }\end{array}$ & $\begin{array}{l}\text { Jumlah } \\
\text { permasalahan yang } \\
\text { ada di desa jabung }\end{array}$ \\
\hline 2 & $\begin{array}{l}\text { Penyuluhan Program kegiatan } \\
\text { pentingnya kebersihan } \\
\text { kesehatan lingkungan }\end{array}$ & $\begin{array}{l}\text { Adanya kesadaran } \\
\text { pengrajin topeng } \\
\text { dalam pengelolaan } \\
\text { limbah dan } \\
\text { kebersihan } \\
\text { lingkungan }\end{array}$ & $\begin{array}{l}\text { Keseluruhan } \\
\text { penggiat topeng } \\
\text { malangan di jabung } \\
\text { antusias antusian } \\
\text { datang mengikuti } \\
\text { penyuluhan. }\end{array}$ \\
\hline 3 & $\begin{array}{l}\text { Pendampingan penataan tempat } \\
\text { produksi topengdan souvenir }\end{array}$ & $\begin{array}{l}\text { Adanya penataan } \\
\text { tempat produksi } \\
\text { yang lebih bersih } \\
\text { dan sehat }\end{array}$ & $\begin{array}{lr}\text { Terdapat } & \text { perbedaan } \\
\text { yang } & \text { signifikan } \\
\text { setelah } & \text { adanya } \\
\text { penataan } & \text { tempat } \\
\text { produksi } & \text { yang } \\
\text { terlihat } & \text { secara } \\
\text { langsung dilokasi. }\end{array}$ \\
\hline 4 & Hasil kebermanfaatan program & $\begin{array}{l}\text { Masalah yang } \\
\text { berhasil } \\
\text { teridentifikasi yang } \\
\text { ada di desa jabung } \\
\text { dan } \\
\text { kebermanfaatan } \\
\text { program. }\end{array}$ & $\begin{array}{l}\text { Terdapat } \\
\text { permasalahan yang } \\
\text { terjawab / } \\
\text { terselesaiakan. }\end{array}$ \\
\hline
\end{tabular}

\section{HASIL DAN PEMBAHASAN}

Pengabdian kepada masyarakat khususnya di desa jabung ini dilakukan dengan pendekatan berbasis masalah yang ada dilokasi yang berbasis tema kesehatan 
lingkungan.Tahapan-tahapan awal yang dilakukan dalam pemecahan masalah adalah 1) survey lokasi, 2) indentifikasi masalah. Tahapan tersebut dilakukan untuk mengatahui situasi dan kondisi masalah dilapangan dengan cara wawancara dan tanya jawab langsung dengan para penggiat topeng malangan di desa jabung kabupaten Malang.

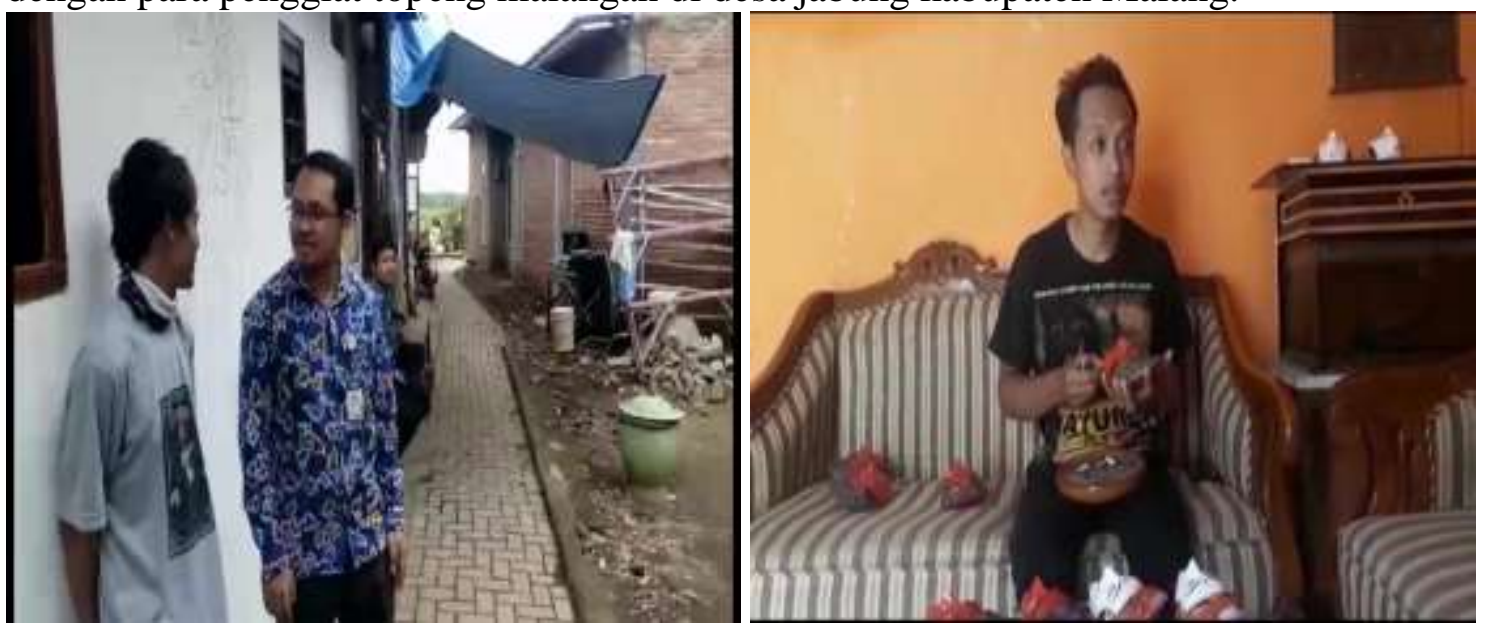

Gambar 2 Survey dan Wawancara Dengan Penggiat Topeng

Berikut hasil atau outcome dalam pemecahan masalah dilapangan :

Pertama kondisi yang membuktikan bahwa mitra belum banyak memiliki kesadaran lingkungan adalah ketika memproduksi kerajinan topeng malangan dan melakukan pemahatan tidak menggunakan masker untuk melindungi pernafasan dari serpihan pahatan kayu dan bau cat. Sehingga hal ini berdampak terhadap kesehatan para pengrajin. Apabila tidak dilakukan edukasi atau penyuluhan maka tentang pentingnya memakai masker maka tidak akan ada kesadaran para pengrajin topeng malangan. Setelah dilakukan penyuluhan yang bertema kesehatan lingkungan tersebut para penggiat topeng malangan mulai sadar benefit yang diterima dari penggunaan masker. Harapan dari tim dengan adanya penyluhan tersebut adalah terjaga kesehatan para pengrajin dari bahaya serpihan pahatan kayu dan pengecatan dalam pembuatan topeng sehingga produktifitas penggiat ataupun pengrajin topeng semakin baik.

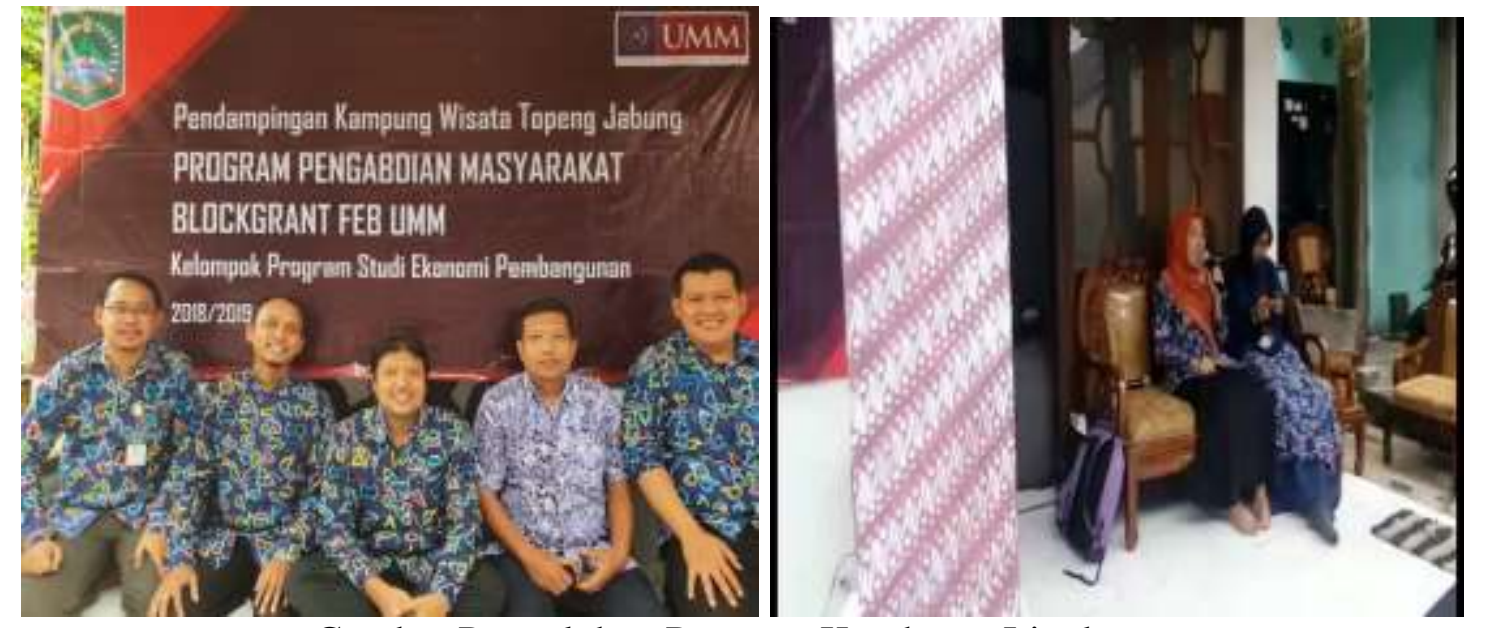

Gambar Penyuluhan Program Kesehatan Lingkungan

Kedua kondisi yang terjadi di lokasi mitra dari kondisi tempat produksi para pengrajin topeng adalah tidak tertata dengan rapi ataupun terlihat kurang nyamannya kegiatan 
produksi topeng. Selain itu kurangnya penerangan apabila produksi dilakukan di malam hari. Kurang luasnya tempat produksi sehingga menambah kurang nyamannya kegiatan produksi. Jadi dari permsalahan mitra tersebut tim melakukan pemahaman pentingnya penataan tempat produksi yang nyaman dan pemanfaatan luas lokasi produksi yang efisien. Tim dan swadaya penggiat topeng membuat almari serbaguna untuk menyimpan alat-alat produksi yang memaksimalkan space / ruangan yang ada. Outcome dari penataan lokasi tersebut adalah lebih terasa luas nyaman dan pencahayaan yang cukup dari pemanfaat ruang yang ada sehingga tercipta rasa nyaman ketika para penggiat topeng berproduksi.
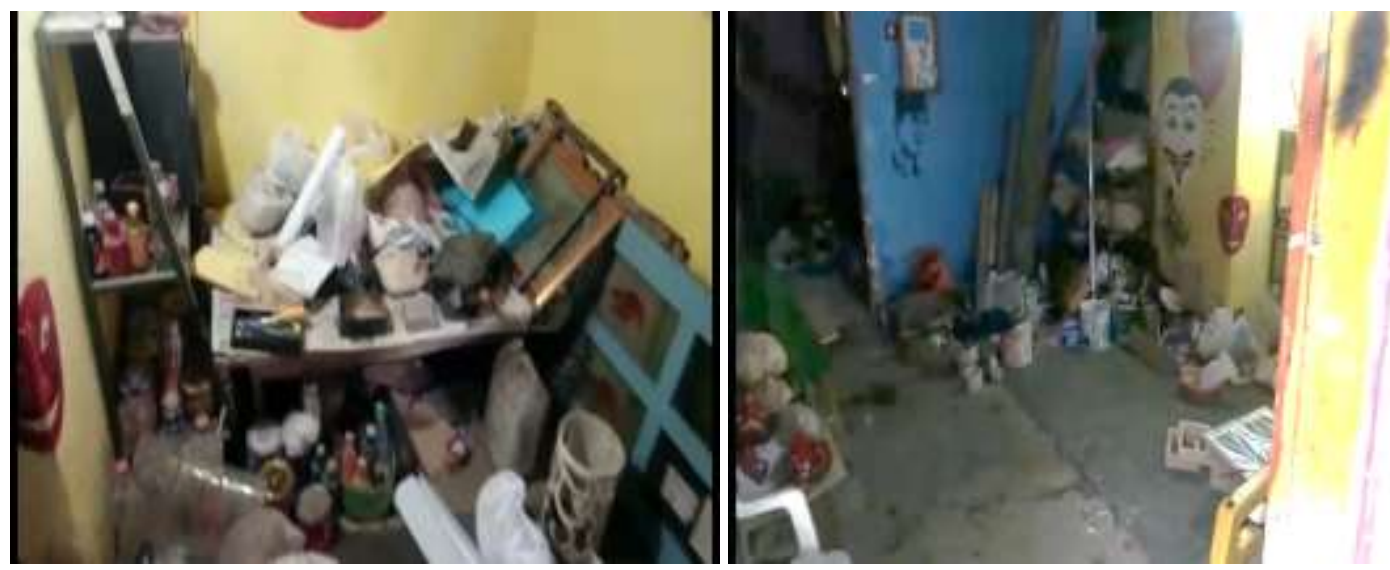

Gambar 3 Tempat Produksi Topeng Sebelum Ada Penataan Tempat Produksi

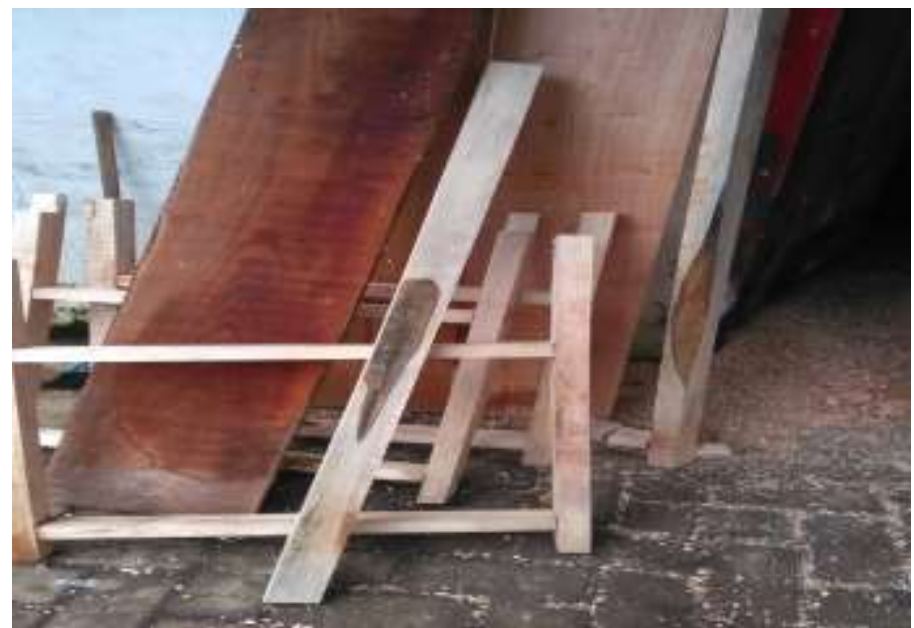

Gambar 4 Bahan Pembuatan Tempat Penyimpanan Peralatan 

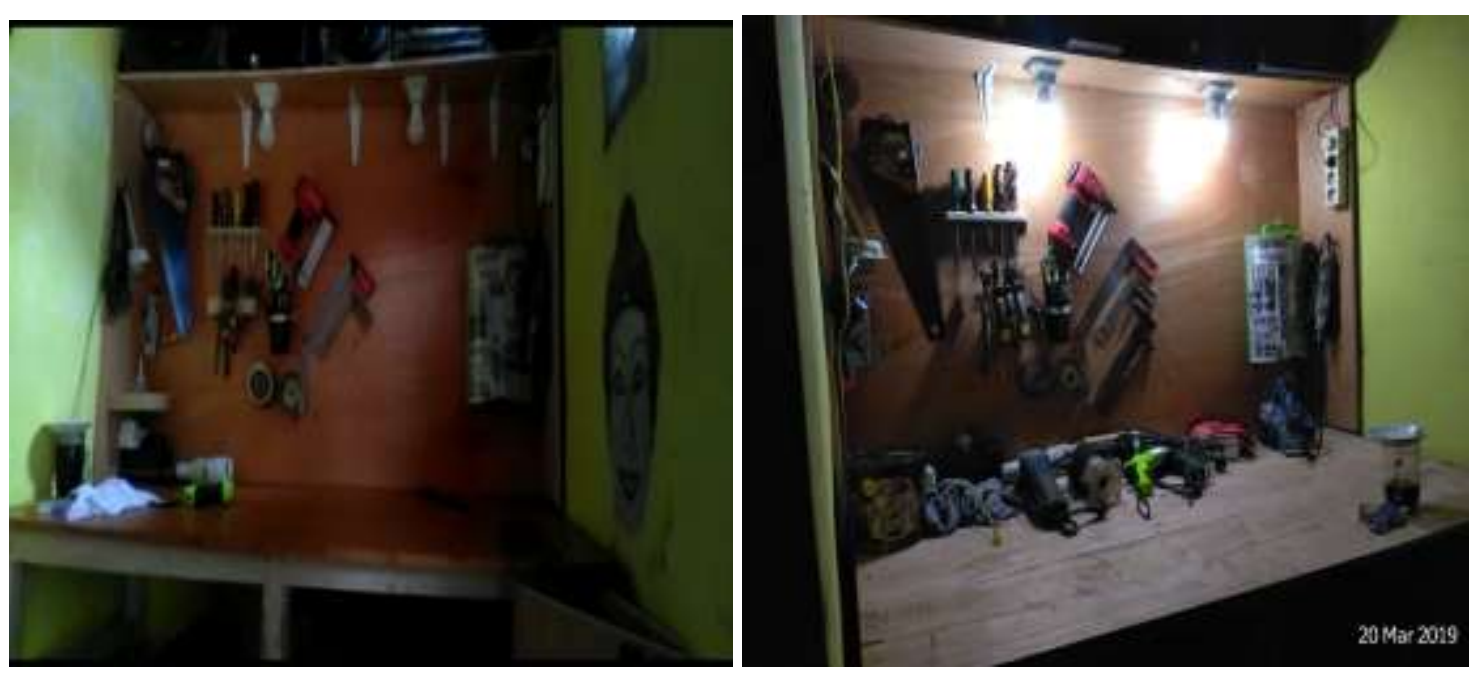

Gambar 5 Setelah Penataan Tempat Produksi
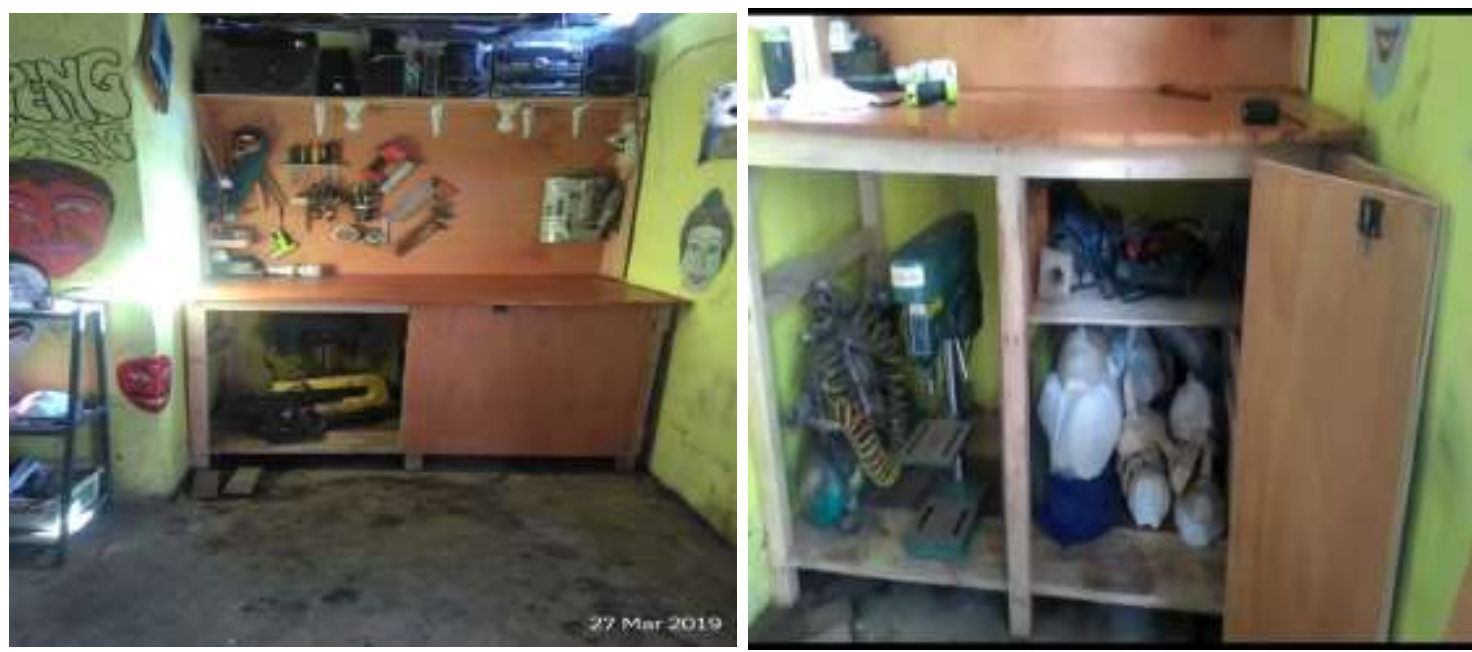

Gambar 6 Tempat Peralatan Produksi Topeng

\section{KESIMPULAN DAN SARAN}

Kesimpulan dari pelaksanaan program kegiatan pengabdian di desa jabung kabupaten malang yaitu:

1. Dengan adanya program penyuluhan kesehatan lingkungan pada pengrajin ataupun penggiat topeng dan souvenir muncul adanya kesadaran mereka akan kebersihan lingkungan tempat produksi. Mitra sadar akan pentingnya menjaga kesehatan dan kebersihan lingkungan. Keinginan kelompok pengrajin (mitra) berharap ada keberlanjutan program-program sejenis yang memberi nilai tambah desa mereka dari eksistensi kampung topeng.

2. Dengan adanya program penataan tempat produksi pengrajin ataupun penggiat topeng dan souvenir maka mitra memperoleh kenyamanan dalam berproduksi. Dengan adanya kenyamanan maka sesuai yang di jelaskan (Simungan, 2005) produktifitas tenaga kerja dipengaruhi salah satunya yaitu lingkungan kerja yang mendukung. Dengan adanya produktifitas yang tinggi maka akan menambah penghasilan para pengrajin topeng dan souvenir di desa jabung kabupaten Malang. 
Saran dari pelaksanaan program kegiatan pengabdian di desa jabung kabupaten malang. Berdasarkan hasil dari pemecahan masalah para pengrajin perlu adanya keberlanjutan program pemberdayaan serta dukungan pemerintah untuk tetap menjaga keberadaan kesenian topeng malangan agar tidak hilang ke generasi selanjutnya dan terjaga kelestariannya.

\section{UCAPAN TERIMA KASIH (OPTIONAL)}

Ucapan terimakasih kami ucapkan untuk terselenggara program pebandian kepada masyarakat atas pendanaan yang diberikan oleh Universitas Muhammadiyah Malang melali dana Block Grant Fakultas Ekonomi dan Bisnis.

\section{REFERENSI}

Fauzi. (2010). Ekonomi Sumber Daya Alam dan Lingkungan Teori dan Aplikasi. Jakarta: PT Gramedia Pustaka Utama.

Kementerian Desa, P. D. T. D. T. (2015). Indeks desa membangun. Jakarta.

Oktafiani, Y. (2016). Hubungan Program Keselamatan Dan Kesehatan Kerja ( K3 ) Dengan Produktivitas Studi Kasus : Bagian Pengolahan Pt . Perkebunan Nusantara XIII, 4(1), 172-183.

Simungan, M. (2005). Produktivitas: Apa dan Bagaimana? (2nd ed.). Jakarta: PT. Bumi Askara.

Widyawati, E. (2014). Valuasi Ekonomi Cultural Heritage Dengan Menggunakan Travel cost, Contingent Valuation Method Dan Income Aproach. UGM. 
